\title{
Profil Harga Diri Siswa dan Implikasinya Bagi Program Bimbingan dan Konseling Pribadi Sosial
}

\author{
Syifa Iftikhar ${ }^{1}$, Rahmawati $^{2}$, Deasy Yunika Khairun ${ }^{3}$ \\ Universitas Sultan Ageng Tirtayasa \\ Email : syifaiftikhar@gmail.com
}

\begin{abstract}
This study aims to determine the self-esteem of grade VII students of SMP Negeri 7 Serang City for the 2019/2020 academic year. The research method used in this research is descriptive with a quantitative approach. The research subjects were 195 grade VII students. The data collection technique used a scale to measure students' self-esteem which consisted of a questionnaire in the form of a questionnaire of 55 items. The aspects of self-esteem consist of strength, meaning, virtue, and ability. Based on the results of the measuring instrument test, it was obtained the validity of 37 valid items and for the reliability test results of 0.812 with a very strong / high classification. After conducting research on students, it was found that the results of the selfesteem of class VII students of SMP Negeri 7 Serang City were in the medium category with a percentage of $68.72 \%$ as many as 134 students, $14.87 \%$ as many as 29 students were in the low category, and $16.41 \%$ as many as 32 students were in the high category . So from this description it is necessary to provide personal social counseling and guidance services for class VII students of SMP Negeri 7 Serang City.
\end{abstract}

Keywords : self-esteem, social personal counseling and guidance program

Open Access

Received : 2020-11-24. Published : 2021-01-31.

This is an open access article distributed under the terms of the Creative Commons Attribution 4.0 International License

Website: http://ejournal.umpri.ac.id/index.php/fokus

\section{PENDAHULUAN}

Pendidikan merupakan kebutuhan dasar bagi setiap orang yang ingin belajar dan berubah menjadi suatu individu bermutu dan berkembang. Sesuai dengan pendapat Aliwanto (2017:65) sekolah adalah tumpuan utama warga negara untuk mengetahui apakah berhasil atau tidaknya suatu pendidikan berlangsung. Menurut Anni (dalam Nugraha, 2016:1) siswa diharuskan aktif dalam kegiatan belajar mengajar, perubahan yang harus disadari dalam dirinya seperti bertambahnya pengetahuan, meningkatnya keterampilan, berubahnya perilaku menjadi lebih baik, kecakapan verbal lebih luas, mampu berpikir secara intelektual, matangnya kognitif serta motorik, dan berupaya mencapai tujuan belajar di kelas sebaik mungkin hingga menghasilkan suatu bentuk prestasi akademik dari hasil belajar.

Namun, tak jarang ada saja siswa yang merasa kurang percaya diri dan bahkan tak jarang merasa putus asa dan rendah diri. Seperti yang dijelaskan Erikson (dalam Hurlock, 2011:208) bahwa remaja mencari identitasnya agar mampu menunjukkan siapa dirinya. Bagaimana peran dirinya di masyarakat, seorang anak-anak atau dewasa, dapatkan dirinya percaya diri meski memiliki riwayat suku, adat, ras dan agama berbeda yang sewaktu-waktu bisa membuat orang lain merendahkannya dan di masa depan, bisakah dirinya berhasil mencapai apa yang diinginkan atau justru tidak. 
Penelitian yang dilakukan Safa'ati dan Setiawati (2013:210) pada SMA Negeri 1 Boureno, memperlihatkan 30 siswa total di kelas X-3, sebanyak 37\% diantaranya adalah siswa dengan kecenderungan harga diri rendah. Berdasarkan hasil Angket Kebutuhan Siswa (AKPD) yang telah dilakukan terhadap siswa kelas VII SMP Negeri 7 Kota Serang menunjukkan kecenderungan memiliki harga diri rendah dengan angka $2,24 \%$ untuk pernyataan 'saya merasa rendah diri', dan angka $1,64 \%$ untuk pernyataan 'saya merasa pesimis bisa naik kelas' yang mana menyebabkan perilaku harga diri rendah seperti, malu untuk berinteraksi dengan guru dan staf sekolah, belum cepat beradaptasi dengan lingkungan baru terutama peralihan dari Sekolah Dasar (SD) ke Sekolah Menengah Pertama (SMP), merasa sulit bergaul dengan teman sebaya dan berinteraksi dengan lawan jenis.

Siswa adalah anak didik yang berada di suatu instansi pendidikan berjenjang yaitu, Sekolah Dasar (SD), Sekolah Menengah Pertama (SMP), dan Sekolah Menengah Atas (SMA). Siswa diharapkan dapat menjadi seseorang yang mandiri, berpengetahuan, memiliki keterampilan, dan terasah kepribadiannya. Hurlock (Hidayati, 2016:137) yaitu masa remaja awalnya berada pada kisaran usia 13 sampai dengan 17 tahun, lalu kemudiaan berakhir pada usia 17 atau 18 tahun. Dengan demikian, banyak perubahan yang terjadi mulai dari aspek fisik, psikis, hingga cara berpikir, dimana hal tersebut berkaitan dengan intelegensi remaja tersebut. Sehingga cara berpikir remaja tersebut terkadang menjadi sumber utama dari interaksi sosial dengan orang lain.

Masa remaja merupakan masa pencarian identitas diri, dimana harga diri menjadi poin penting untuk mendukung pencarian jati diri remaja tersebut. Aspekaspek harga diri dijelaskan oleh Coopersmith (Nur, 2013:3) adalah kekuatan (power), keberartian (significance), kebajikan (virtue), kemampuan (competence). Kekuatan merujuk pada bagaimana seseorang dapat menguasai, mengontrol dan mengatur perlakuan diri serta adanya pengakuan perlakuan diri tersebut dari orang lain. Keberartian memiliki cakupan seperti, kepedulian, perhatian, afeksi, dan ekspresi cinta yang seseorang terima dari orang lain. Kebajikan adalah Seseorang taat aturan dalam mengikuti standar etika, agama, dan moral. Kemampuan merujuk pada kemampuan performansi tinggi dan kemampuan tugas-tugas yang diberikan pada pemenuhan utuh pencapaian prestasi atas apa yang sudah dilakukan seseorang dan berhasil.

Bidang pribadi dan sosial adalah bidang pribadi banyak menyangkut masalah yang berkaitan dengan diri suatu seseorang. Aspek pribadi-sosial adalah salah satu yang sangat penting diperhatikan oleh siswa selain aspek karir dan belajar. ABKIN (Amalina, 2013:4) menyebutkan bahwa dalam aspek pengembangan pribadi sosial diharapkan siswa mampu mengenal keinginan maupun kemampuan diri dan menerima diri apa adanya. Oleh karena itu, program bimbingan dan konseling untuk meningkatkan harga diri siswa sangat dibutuhkan bagi referensi guru bimbingan dan konseling ketika menemukan siswa dengan masalahharga diri siswa yang rendah serta belum sepenuhnya tinggi atau dapat dikatakan sedang dan peneliti selanjutnya untuk mengeksperimenkan konseling atau pendekatan dalam teknik tertentu agar harga diri suatu seseorang tinggi.

\section{METODE}

Metode yang digunakan dalam penelitian ini adalah metode deskriptif dengan pendekatan kuantitatif. Bertujuan untuk mendapatkan gambaran lengkap mengenai harga diri siswa. Lokasi penelitian yaitu SMP Negeri 7 Kota Serang yang terletak di Jl. Penancangan Baru No.36, Panancangan, Kec. Serang, Kota Serang, Banten. Subjek penelitian adalah siswa/i kelas VII dengan keseluruhan populasi sebanyak 380, kemudian ditentukan jumlah sampel dari populasi untuk batas kesalahan toleransi $0.05 \%$, sehingga menghasilkan jumlah sampel sebanyak 195 orang. Teknik pengumpulan sampel pada penelitian ini yaitu menggunakan simple random sampling. 
Skala yang digunakan adalah Likert serta, alat pengumpulan data memakai kuesioner dengan skala ukur harga diri sebanyak 55 butir dengan nilai reliabilitas 0.812 dengan data yang diperoleh dianalisis menggunakan teknik analisis kuantitatif deskriptif.

\section{HASIL DAN PEMBAHASAN}

Berdasarkan data mengenai harga diri siswa kelas VII tahun ajaran 2019/2020 di SMP Negeri 7 Kota Serang diperoleh dari kuesioner atau angket dan disebar kepada sampel penelitian yang berjumlah 195 responden menunjukan hasil sebagai berikut.

Tabel 1. Gambaran Harga Diri Siswa

\begin{tabular}{|c|c|c|c|c|}
\hline Variabel & Kategori & Rentang Skor Nilai & Frekuensi & Persentase \\
\hline \multirow{4}{*}{ Harga Diri } & Rendah & $\mathrm{X}<107.45$ & 29 & $14.87 \%$ \\
\hline & Sedang & $107.45 \leq \mathrm{X}<126.15$ & 134 & $68.72 \%$ \\
\hline & Tinggi & $126.15 \leq \mathrm{X}$ & 32 & $16.41 \%$ \\
\hline & \multicolumn{2}{|c|}{ Total } & 195 & $100 \%$ \\
\hline
\end{tabular}

Berdasarkan tabel diatas, menunjukkan gambaran harga diri siswa termasuk dalam kategori sedang yakni sebanyak 134 siswa dengan persentase $68.72 \%$, sementara 32 siswa dengan persentase $16.41 \%$ berada pada kategori tinggi dan 29 siswa lainnya dengan persentase $14.87 \%$ berada pada kategori rendah.

Selanjutnya, gambaran harga diri siswa berdasarkan indikator dapat dilihat pada tabel berikut.

1. Kekuatan (power)

Tabel 2. Kekuatan (power)

\begin{tabular}{|l|l|l|l|l|}
\hline Variabel & Kategori & Rentang Skor Nilai & Frekuensi & Persentase \\
\hline Harga Diri & Rendah & $\mathrm{X}<16.61$ & 32 & $16.42 \%$ \\
\cline { 2 - 5 } & Sedang & $16.61 \leq \mathrm{X}<21.04$ & 141 & $72.30 \%$ \\
\cline { 2 - 5 } & Tinggi & $21.04 \leq \mathrm{X}$ & 22 & $11.28 \%$ \\
\hline \multicolumn{2}{|c|}{ Total } & 195 & $100 \%$ \\
\hline
\end{tabular}

Berdasarkan tabel di atas sebagian besar siswa termasuk pada kategori sedang yakni sebanyak 141 siswa dengan persentase $72.30 \%$. Sementara sebanyak 32 siswa dengan persentase $16.42 \%$ berada pada kategori rendah dan sebanyak 22 siswa dengan persentase $11.28 \%$ berada pada kategori tinggi. Indikator kekuatan (power) berada pada kategori sedang. Hal ini berarti sebagian besar siswa sudah memiliki aspek harga diri pada indikator kekuatan (power). Akan tetapi, jelas belum sepenuhnya dapat menguasai, mengatur dan mengontrol perilaku diri serta mendapat pengakuan atas tingkah laku dari orang lain. Rosenberg (Yusuf, 2012:229) menjelaskan bahwa pengaruh harga diri dengan mendapatkan pengakuan dan tingkah laku dari orang lain menunjukkan jika seseorang tersebut diterima dan dihargai ide serta haknya, terutama saat mengutarakan pendapat. Karena jika seseorang mendapat apresiasi maka pribadinya akan kuat, otomatis harga diri seseorang tersebut akan tinggi. Oleh sebab itu, masih diperlukannya peningkatan dalam pemberian pengakuan dari orang lain terhadap perilaku seseorang. 
Syifa Iftikhar, Rahmawati, Deasy......

\section{Keberartian (significance)}

Tabel 3. Keberartian (significance)

\begin{tabular}{rllll}
\hline Variabel & Kategori & Rentang Skor Nilai & Frekuensi & Persentase \\
\hline Harga Diri & Rendah & $\mathrm{X}<30.51$ & 28 & $14.36 \%$ \\
& Sedang & $30.5 \leq \mathrm{X}<37.89$ & 129 & $66.15 \%$ \\
& Tinggi & $37.89 \leq \mathrm{X}$ & 38 & $19.49 \%$ \\
Total & & & 195 & $100 \%$ \\
\hline
\end{tabular}

Berdasarkan tabel di atas sebagian besar siswa termasuk pada kategori sedang yakni sebanyak 129 siswa dengan persentase 66.15\%. Sementara sebanyak 28 siswa dengan persentase $14.36 \%$ berada pada kategori rendah dan sebanyak 38 siswa dengan persentase $19.49 \%$ berada pada kategori tinggi. Sebagian besar siswa sudah memiliki aspek harga diri pada indikator keberartian (significance). Akan tetapi, jelas belum sepenuhnya siswa menerima kepedulian, perhatian, afeksi dan ekspresi cinta dari orang lain. Aspek perhatian sangat dibutuhkan dalam pendidikan. Menurut Al-Ghazali (Dedih, dkk. 2019:6-7) perhatian merupakan kegiatan jiwa yang berpusat pada satu objek. Jadi, selain siswa yang sudah memusatkan perhatiannya pada guru dengan cara mengikuti proses belajar mengajar, guru juga bisa memberikan rasa perhatiannya ke siswa sehingga proses belajar di kelas dapat berjalan dengan baik. Rasa peduli, selain penting juga merupakan salah satu bentuk sikap dalam bersosialisasi. Menurut Cronbach (dalam Munthe dan Santoso, 2018:120) afeksi adalah suatu kebutuhan seseorang yang ingin direspon atau diperlakukan hangat oleh orang lain. Aspek ekpresi cinta mengindikasikan bahwa setiap orang berhak atas perasaan dicintai.

\section{Kebajikan (virtue)}

Tabel 4. Kebajikan (virtue)

\begin{tabular}{cllcr}
\hline Variabel & Kategori & Rentang Skor Nilai & Frekuensi & Persentase \\
\hline Harga Diri & Rendah & $\mathrm{X}<34.21$ & 35 & $17.95 \%$ \\
& Sedang & $34.21 \leq \mathrm{X}<41.44$ & 124 & $63.59 \%$ \\
& Tinggi & $41.44 \leq \mathrm{X}$ & 36 & $18.46 \%$ \\
Total & & & 195 & $100 \%$ \\
\hline
\end{tabular}

Berdasarkan tabel di atas sebagian besar siswa termasuk pada kategori sedang yakni sebanyak 124 siswa dengan persentase $63.59 \%$. Sementara sebanyak 35 siswa dengan persentase $17.95 \%$ berada pada kategori rendah dan sebanyak 36 siswa dengan persentase $18.46 \%$ berada pada kategori tinggi. Hal ini berarti sebagian besar siswa sudah memiliki aspek harga diri pada indikator kebajikan (virtue) akan tetapi belum sepenuhnya siswa menjalankan ketaatan moral, ketataan etika, dan ketaatan agama. Menurut Budiningsih (dalam Widiharto, 2011:3) moral adalah bagaimana cara seseorang untuk memutuskan mana hal yang baik, mana yang tidak. Bukan hanya menentukan sesuatu tersebut baik dan buruk. Hal ini berarti orang tua memiliki peran signifikan terhadap moral anak, terlebih keluarga adalah tempat pertama anak-anak menjalani kehidupan. Ya'qub dalam (Tas'adi, 2014:192) yaitu etika dijalankan sebagai bentuk seseorang berperilaku sesuai dengan apa seharusnya dilakukan (baik) dan tidak dilakukan (buruk) tetapi tetap pada peraturan yang berlaku. Yusuf (dalam Purwadi dan arief, 2016:4) setiap manusia diberikan anugerah berupa insting naluri beragama (religius) yang dapat memengaruhi norma sosial. Dengan demikian, jika remaja yang sudah mulai kritis terhadap pencarian keyakinannya, lalu mempelajarinya dengan baik, maka secara bertahap akan membentuk sikap yang tidak berjauhan dengan setiap norma dimana dia tinggal. 
Profil Harga Diri Siswa dan Implikasinya bagi Program....

4. Kemampuan (performances)

Tabel 5. Kemampuan (performance)

\begin{tabular}{ccccc}
\hline Variabel & Kategori & Rentang Skor Nilai & Frekuensi & Persentase \\
\hline \multirow{4}{*}{ Harga Diri } & Rendah & $\mathrm{X}<22.38$ & 27 & $13.85 \%$ \\
& Sedang & $22.38 \leq \mathrm{X}<29.48$ & 136 & $69.74 \%$ \\
& Tinggi & $29.48 \leq \mathrm{X}$ & 32 & $16.41 \%$ \\
& & & 195 & $100 \%$ \\
\hline
\end{tabular}

Berdasarkan tabel di atas sebagian besar siswa termasuk pada kategori sedang yakni sebanyak 136 siswa dengan persentase $69.74 \%$. Sementara sebanyak 27 siswa dengan persentase $13.85 \%$ berada pada kategori rendah dan sebanyak 32 siswa dengan persentase $16.41 \%$ berada pada kategori tinggi. Kemampuan (competence) memiliki dua aspek yaitu kemampuan performansi dan kemampuan tugas-tugas. Hasil indikator kemampuan (competence) dengan aspek kemampuan performansi ada pada kategori sedang. Pentingnya kemampuan performansi bagi harga diri siswa sesuai dengan pendapat Heatherton dan Polivry (dalam Mahmuda, 2017:33) yaitu perasaan terhadap kompetensi seperti, kemampuan intelektual, regulasi diri, rasa percaya diri, dan efikasi diri dimana jika hal tersebut dirasa bisa dilakukan, maka dapat membuat seseorang memiliki harga diri yang tinggi. Dengan demikian, jika seseorang memiliki kemampuan performansi secara baik, maka tidak diragukan lagi harga dirinya akan terbilang tinggi.

Berdasarkan analisis hasil penelitian mengenai harga diri siswa, penulis merancang program Bimbingan Pribadi Sosial. Program yang dirancang dalam penelitian mengenai harga diri siswa kelas VII di SMP Negeri 7 Kota Serang yaitu program bimbingan pribadi sosial. Hal-hal yang dibutuhkan dalam merancang program bimbingan pribadi sosial, yaitu data yang akan menjadi acuan dalam merancang program bimbingan pribadi sosial. Data yang digunakan yaitu data hasil analisis instrumen mengenai harga diri siswa kelas VII SMP Negeri 7 Kota Serang.

Hasil pengolahan data angket diperoleh persentase tertinggi yaitu di kategori rendah pada sub indikator ketaatan agama dengan persentase $25.12 \%$ sebanyak 49 siswa, lalu pada sub indikator ketaatan moral dengan persentase $22.05 \%$ sebanyak 43 siswa, dan pada sub indikator kepedulian dengan persentase $22.05 \%$ sebanyak 43 siswa. Dengan demikian hasil tersebut dijadikan sebagai dasar kebutuhan siswa dalam penyusunan rancangan program bimbingan pribadi sosial.

Strategi layanan yang dapat diberikan kepada siswa beragam. Namun, perlu disesuaikan dengan kebutuhan siswa. Strategi layanan yang dapat diterapkan yaitu bimbingan klasikal, bimbingan lintas kelas, bimbingan kelompok, konseling kelompok, konseling individu, dan sebagainya. Adapun komponen layanan yang digunakan yaitu layanan dasar, layanan responsif, layanan perencanaan individual, dan dukungan sistem. Menurut Sudrajat (Nurihsan, 2005:28) layanan dasar merupakan pemberian bantuan pada siswa melalui kegiatan klasikal atau kelompok secara sistematis agar siswa mampu berkembang optimal. Layanan dasar lebih mengutamakan bimbingan dalam skala besar seperti di kelas, bimbingan kelas besar, dan bimbingan kelompok. Bidang layanan dasar mencakup pribadi, sosial, belajar, dan karir dimana siswa diharapkan untuk memiliki potensi yang lebih berkembang di tiap bidang tersebut.

Rahmat (2019:42) dalam jurnalnya menjelaskan bahwa layanan responsif merupakan layanan yang diberikan pada siswa untuk menangani permasalahannya dengan segera. Penanganan dan pertolongan tersebut jika tidak diberikan langsung makan dapat membuat suatu gangguan dalam mencapai tugas perkembangan siswa 
tersebut. Menurut Lutfiyani dan Caraka (2017:374) dalam jurnalnya menjelaskan bahwa layanan perencanaan individual merupakan bimbingan bagi siswa untuk membuat rencana terkait bidang pribadi, sosial, belajar dan karir, memonitor, kemudian dikelola oleh siswa tersebut. Lutfiyani dan Caraka (2017:374) dalam jurnalnya yaitu dukungan sistem adalah komponen yang lebih diarahkan pada manajemen pemberian kegiatan dan layanan bermanfaat bagi siswa.

\section{KESIMPULAN}

Berdasarkan hasil profil mengenai harga diri siswa kelas VII di SMP Negeri 7 Kota Serang Tahun Ajaran 2019/2020, didapatkan bahwa harga diri siswa berada pada kategori sedang dengan jumlah persentase yaitu $68.72 \%$. Hal ini menunjukkan bahwa sebagian besar siswa telah memiliki karakteristik harga diri cukup baik, namun belum sepenuhnya memperlihatkan karakteristik harga diri tinggi seperti yang ditunjukkan siswa dengan harga diri tinggi. Maka dari itu, diperlukan peningkatan yang lebih baik lagi agar karakteristik harga diri tinggi dapat tercapai semaksimal mungkin. Aspek harga diri pada indikator kekuatan (power) diperoleh hasil persentase $72.30 \%$ yang berada pada kategori sedang. Kemudian indikator keberartian (significance) diperoleh hasil persentase $66.15 \%$ yang berada pada kategori sedang. Indikator selanjutnya adalah kebajikan (virtue) diperoleh hasil persentase $63.59 \%$ yang berada pada kategori sedang. Terakhir adalah indikator kemampuan (competence) diperoleh hasil persentase $69.74 \%$ yang berada pada kategori sedang.

Oleh sebab itu, meski harga diri siswa kelas VII di SMP Negeri 7 Kota Serang berada pada kategori sedang, dimana bisa dikatakan sudah cukup baik. Jelas masih diperlukannya peningkatan secara signifikan agar seluruh siswa baik yang berada pada kategori sedang dan rendah dapat menjadi lebih baik lagi dan berada pada karakteristik harga diri yang tinggi. Dengan demikian, rancangan program bimbingan pribadi dan sosial dapat dijadikan pedoman untuk pemberian layanan yang komprehensif bagi kebutuhan siswa. Sehingga diharapkan rancangan program bimbingan pribadi sosial dapat membantu meningkatkan karakteristik siswa dalam pencapaian harga diri yang tinggi.

\section{DAFTAR PUSTAKA}

Aliwanto. (2017). Analisis aktivitas belajar siswa. Jurnal Konseling Jurusan Bimbingan dan Konseling FKIP Universitas Muria Kudus, 3, 64-71. https://dx.doi.org./10.24176/jkg.v3i1.1112/ 20.02.20. 23:26

Amalina, S. S. N. (2013). Pengembangan program bimbingan pribadi-sosial berdasarkan profil harga diri (self-esteem) siswa. Skripsi Jurusan Psikologi Pendidikan dan Bimbingan Fakultas Ilmu Pendidikan Universitas Pendidikan Indonesia. repository.upi.edu/ 15.01.20. 10:09

Dedih, U., Qiqi. Y. Z., dan Jeri, O. M. (2019). Pehatian orang tua dalam pendidikan keagamaan anak di rumah hubungannya dengan perilaku mereka di lingkungan sekolah. Jurnal Program Studi Pendidikan Agama Islam, FTK Universitas Islam Negeri Sunan Gunung Djati Bandung, 1. 1-23. journal.uinsgd.ac.id/ 06.09.20. $12: 42$

Hidayati, K. B., dan Muhammad, F. (2016). Konsep diri adversity quotient dan penyesuaian diri pada remaja. Jurnal Psikologi Indonesia Universitas 17 Agustus 1945 Surabaya, 5. 137-144. jurnal.untag-sby.ac.id/ 21.07.20. 19:45

Hurlock, E. B. (2011). Psikologi perkembangan : suatu pendekatan sepanjang rentang kehidupan. Jakarta: Erlangga 
Lutfiyani, V., dan Caraka, P. B. (2017). Strategi layanan bimbingan dan konseling komprehensif dalam pengembangan self-knowledge pada siswa sekolah dasar. Jurnal SENDIKA: Seminar Nasional Pendidikan Fakultas Keguruan dan Ilmu Pendidikan Universitas Ahmad Dahlan, 1. 370-377. eprints.uad.ac.id/ 12.09.20. $13: 21$

Mahmuda, I. (2017). Hubungan harga diri dengan kepercayaan diri pada komunitas cosplayer medan (cosmed). Skripsi Fakultas Psikologi Universitas Medan Area. repository.uma.ac.id/ 08.09.20 15:55

Munthe, I. S., dan Santoso, T. R. (2018). Pemenuhan kebutuhan afeksi pada anak (peningkatan kemandirian dan kepercayaan diri di lembaga kesejahteraan sosial anak - LKSA). Jurnal Pekerjaan Sosial Program Studi Kesejahteraan Sosial Fakultas Ilmu Sosial dan Ilmu Politik, 2. 119-123. researchgate.unpad.ac.id/ 06.09.20 14:50

Nugraha, C. (2016). Penerapan model pembelajaran student facilitator and explaining (SFAE) untuk meningkatkan hasil belajar siswa pada mata pelajaran instalasi penerangan listrik di smk negeri 4 bandung. Skripsi Jurusan Pendidikan Teknik Elektro Fakultas Pendidikan Teknologi dan Kejuruan Universitas Pendidikan Indonesia. repository.upi.edu/ 23.02.20. 10:13

Nur, F. (2013). Hubungan antara harga diri dengan penyesuaian diri pada santri remaja tahun pertama 2012/2013 di pondok pesantren modern raden paku trenggalek. Skripsi Fakultas Psikologi Universitas Islam Negeri (UIN) Maulana Malik Ibrahim Malang. etheses.uin-malang.ac.id/ 26.09.18. 18:56

Nurihsan, A. J. (2005). Strategi layanan bimbingan dan konseling. Bandung: PT. Refika Aditama

Purwadi dan Arief, W. (2016). Hubungan antara religiusitas dengan kepercayaan diri. Jurnal Al-Qaib Psikologi Universitas Sumatera Utara, $1.1-7$. https://ejournal.uinib.ac.id/ 08.09.20. 14:18

Rahmat, H. K. (2019). Implementasi strategi layanan bimbingan dan konseling komprehensif bagi siswa tunanetra di mts. yaketunis yogyakarta. Jurnal Penelitian Program Studi Bimbingan dan Konseling Islam Universitas Islam Negeri Sunan Kalijaga, 1. 37-46. ejournal.uin-suka.ac.id/ 13.09.20. 15:04

Safa'ati, M. L., dan Setiawati, D. (2013). Penerapan konseling kelompok kognitif perilaku untuk meningkatkan harga diri siswa. Jurnal Bimbingan dan Konseling Fakultas Ilmu Pendidikan Universitas Negeri Surabaya, 10, 209-214. jurnalmahasiswa.unesa.ac.id/ 22.09.18. 18:53

Tas'adi, R. (2014). Pentingnya etika dalam pendidikan. Jurnal Penelitian Ta'dib Program Studi Bimbingan dan Konseling Sekolah Tinggi Agama Islam Negeri Batusangkar, 2. 189-198. ecampus.iainbatusangkar.ac.id/ 08.09.20. 12:32

Widiharto, A. (2011). Perilaku bullying, harga diri dan pemahaman anak. Jurnal Artikel Universitas Kristen Krida Wacana, 1-8. media.neliti.com/publications/ 08.09.20. 10:32

Yusuf, L., dan Chandra, B. R. (2012). Harga diri pada remaja menengah putri di sma negeri 15 kota semarang. Jurnal Nursing Studies, 1. 225-230. http://ejournalS1.undip.ac.id/index.php/jnursing/ 04.09.20. 14:50 